\title{
A GLIMPSE AT NEW JERSEY COLONIAL POLITICS
}

\section{BY DAVID BERNSTEIN}

Mr. Bernstein is a member of the Department of History in the California State College at Long Branch.

\section{$\mathrm{P}$}

OLITICAL AFFAIRS in the colonial period of American life have been a subject of great importance to the student of history. Numerous studies describe the institutional framework of government, political struggles on the provincial scene, political leadership, and the extent of the suffrage. Few of these works, however, have been able to present any analysis of local factional quarrels and their relationship to colonial political life.

The Special Collections Department of the Rutgers University Library possesses an election broadside of March, I 772, from Cumberland County, New Jersey, which reveals the characteristics of local political warfare. This was the last general election called by the Royal Governor, William Franklin, before the American Revolution. Thirty Assembly seats were to be filled, two from each of the thirteen counties and two representatives from the cities of Perth Amboy and Burlington, the respective capitals of East and West Jersey. The election had been called by Franklin to give three new counties formed in $\mathrm{I} 748$ their proper representation in the Assembly. ${ }^{1}$ Cumberland County was one of these new counties.

The general election of I 772 was contested amid growing tensions between the Assembly and the Governor. The British Ministry in I 769 and I 770 had vetoed two Assembly measures which would have established a provincial Land Bank to alleviate New Jersey's currency shortage. ${ }^{2}$ In the wake of this rebuff the Assembly continued to agitate for a money bill while contesting with Governor Franklin over salaries for government officials and supplies for His

${ }^{1}$ New Jersey Archives, Ist series, XVIII (Trenton, N.J. 1893), 279-280.

${ }^{2}$ Ibid., I 84 ; X, I 50-15I; Joseph Albert Ernst, "Currency in the Era of the American Revolution: A History of Colonial Paper Money Practices and British Monetary Policies, 1764-1781" (unpublished Ph.D. dissertation, Department of History, University of Wisconsin, 1964), 317-320. 
Majesty's troops stationed in New Jersey. ${ }^{3}$ A few months before the election Franklin had been able to get some provision for the troops but failed to achieve higher stipends. ${ }^{4}$

Cumberland County, the subject of the broadside, was a representative area of colonial West Jersey. Its economy, based upon an abundance of rich soil, was predominantly agricultural. A number of merchants, taking advantage of the proximity of the Delaware River, Cumberland's southern boundary, flourished. ${ }^{5}$ The first permanent residents in the county were the Quakers who settled in I686 in Greenwich Township and along the Cohansey Creek in Cumberland's western section. By I 770, however, the Quakers were a minority in a population which was mostly Baptists and Presbyterians. $^{6}$

The Cumberland County election broadside depicted a remarkable degree of political sophistication despite the absence of political parties. Dated March I 5, I 772, the broadside was sent from the Weekly Meeting in Greenwich to the Monthly Meeting in Salem County. ${ }^{7}$ A close association between these two Quaker groups had been established before 1772 when Salem and Cumberland Counties were represented together in the Assembly. The broadside was drawn up to help the Salem Meeting and other Quaker groups achieve similar political victories. The full drama of the Cumberland County contest, including the selecting of candidates by the parties involved, the wooing of the electorate, and the building of political alliances, was presented in great detail.

The Cumberland Society had hoped to have two Quakers elected to the Assembly but knew it was impractical since the majority of the county was Presbyterian, "our mortal enemies." Instead they worked to divide the Presbyterians. John Sheppard, a well-known merchant and member of Greenwich Meeting, became the Quaker candidate. He was a popular man whose business, according to the

${ }^{3}$ Votes and Proceedings of the General Assembly of the Province of New Jersey, 3 rd session, 2 ist assembly, (Burlington, 1772), 46-47 (hereafter cited as Votes and Proceedings); 5th session, 37-39; New Jersey Archives, ist series, XVIII, 307.

${ }^{4}$ Votes and Proceedings, 4th session, 2 ist assembly, 72 ; Ist session, 22 nd assembly, 52.

${ }^{5}$ Alfred M. Heston, et al., South Jersey: A History $1664^{-1924}, 5$ vols. (New York, 1924), II, 937.

${ }^{6}$ Ibid., 956.

7 "From the Weekly Meeting In G-N-H, to the Monthly Meeting in S-M," March 25, I 772, broadside, Rutgers University Library. 
Quakers, had placed many people in his debt and thus partly under his control. Sheppard had prepared for his nomination. He had joined "a number of lower class of people to oppose the Magistrates (which we call the court party)," and he had purchased "some building lots at the bridge, that the people may think he would be in their interest in erecting the fairs there (which they have very much at heart) he being sensible an election would soon come." Sheppard became the Quaker candidate "on our side of the creek."

The creek, known as the Cohansey, split the county east and west. Each faction tried to be sure that it had one candidate from each side of the creek. The same had been true before I 772 when Salem and Cumberland were represented together. The Quaker candidate on the other side of the Cohansey became Theophilus Elmer, from an influential family which stood above the Presbyterian-Quaker squabble. Elmer provided a good second choice from the Quaker viewpoint, especially with his popularity on the other side of the creek. From I 766 to I 769 he had been elected county sheriff. Not beholden to any Presbyterian leader, Elmer could also be of use in splitting the Presbyterian vote.

Andrew Hunter, the Presbyterian leader of the area, had set up an arrangement to put forth two Presbyterian candidates, one from each side of the creek. Maskell Ewing, one of Hunter's deacons, related these plans to the Quakers. Ewing, in the eyes of his Quaker allies, was "the most hidden man you can conceive of, and so avarious [sic], that he will take any part for the sake of interest (for he solicited for the Stamp Office) him we gained, for you know, we don't regard trifles where our cause is at stake." Obviously Hunter did not know of Ewing's duplicity. He and Samuel Fithian were chosen as the Presbyterian candidates. Both men agreed to stand, but Ewing, after making sure of the necessary Presbyterian support for his candidacy, waited until a few days before the election and then withdrew. Hunter, now pressed for time just before the election, asked Theophilus Elmer from Fairfield Township, "a popular man," to be a Presbyterian candidate but he "modestly" refused. Thomas Holmes did accept the position and the two opposing candidates were again set.

To thwart further the Presbyterians, the Friends met with and gained the support of the First and Seventh Day Baptists with the 
help of David Bowen and Providence Ludlam. Bowen, another influential and wealthy merchant, was "near the seventh day Baptists, had them in debt, and of consequence had considerable influence over them, which we knew." Ludlam was "Cape May born, constitutionally a party man." The Quakers also sent to the Dutch, in the upper part of the county, slips of paper with the words "John Sheppard, Theophilus Elmer and Liberty." With their Dutch and Baptist allies safely in the fold, the Quakers now hoped to garner some Presbyterian supporters on the other side of the Cohansey Creek. This they achieved by "inflaming Elmer's friends, in their county cause, and joining their interest with ours against the court party."

Next the Quakers, to harden their alliances, concocted and spread a rumor about the opposition. If the Presbyterians were victorious, whispered the Quakers, the people would be taxed for another Presbyterian provincial college and the government would be established along church lines. Talk of increased and burdensome taxes became rampant. To give the charges substance, it was made to appear that the retiring Assemblyman, Ebenezer Miller, had been the original source of the story. Ludlam unquestionably believed the accusations and campaigned strongly on the other side of the creek, persuading Elmer's followers to endorse the Quaker ticket.

With the poll just a short time away, the Quakers gained the unsolicited allegiance of Silas Newcomb, a neighbor of Elmer's from Fairfield, across the Cohansey. Newcomb used his popularity as an officer in the French and Indian War to "set himself up against Elmer and Holmes," who were the candidates of the two factions on his side of the creek. To be victorious Newcomb needed Quaker support in Greenwich. They made a pact with Newcomb to exchange votes at the polls, but on the first day of the election, the Quakers gave Newcomb only enough votes to keep his interests, but not enough to hurt Elmer's chances.

Another incident, as related by the Quakers, occurred previous to the election and helped their argument for a proper balance of Friends in the Assembly. Some militia were to be raised. "The Presbyterians contended for one thousand; but the Quakers gave them such opposition they could get but five hundred, and after they had raised them, they were so burdensome, they were heartily sick of 
it." It was made to appear that Quaker foresight had triumphed over the Presbyterians' poor judgment.

On election day the plans were set. Not taking anything for granted, the Quakers "kept our tools continually employed through the election, which gained many over to our interest by their unwearied industry." Before the poll was declared open the incumbent Assemblyman Miller, while declining to serve again, a fact obviously well known to all, spoke of the need to elect young men as representatives. This was timely for the Quakers, as they must have known, because the two Presbyterian men, Holmes and Fithian, were older than Sheppard and Elmer. The Quakers, well prepared, brought out the votes as fast as possible; "the other party was very backward." Because the Quakers forged ahead early in the count, the opposition became disheartened and "broke to pieces." John Sheppard and Theophilus Elmer were elected handily.

This broadside, although perhaps exaggerating the facts regarding the Quakers' victory, could not hide the true essence of New Jersey colonial politics. The center of political power was the church and the family. Newcomb did not hesitate to contest Elmer despite their close relationship as neighbors in Fairfield Township. In spite of provincial controversies of the day involving disagreements between the Royal Governor and the Assembly, the Cumberland election was devoid of issues of public policy or ideology. Personal considerations such as religion, family prestige, and pride were apparent, and these factors delineated the opposing forces. The Quakers and Presbyterians, "mortal enemies," plus Ewing, Fithian, Holmes, Sheppard, Newcomb, the Baptists, and the Dutch were concerned with keeping others from the seat of political power rather than with formulating a set of principles and ideals. Even dissident Presbyterian allies were courted by the Quakers, who did not "regard trifles when our cause is at stake." The Quakers, building upon their strong and well disciplined religious organization, sought candidates, campaigned, garnered allies, created issues, propagandized charges against their opponents, and produced the votes on election day. Nominations, as Sheppard and Newcomb illustrated, were sought. These organizations, however, do not mean the creation of

${ }^{8}$ The quotations in this article are all taken from the election broadside of March I 5,1772 . 
political parties. The coalition in $\mathrm{I} 772$ between religious and family groups was only a temporary arrangement. Newcomb did not even realize that the Quakers were using his candidacy for their own ends.

Important to the county's political life was the Cohansey Creek, which separated the area into two distinct sections much as the colony was divided, east and west. The Presbyterian strength was on one side of the creek while the Friends appeared in control of the western portion of the county. Since the largest electoral unit in the province was the county, there was no need for any organization beyond those borders. Localism dictated action and reaction.

The suffrage was extensive. The debtors beholden to Bowen and Sheppard were expected to vote for the proper slate. Obviously creditors were not fearful of using their position to coerce those beholden to them. If a debtor, whose voting habits could be easily detected under the viva voce method, did not signify the proper man, it might be possible for his creditors to insist upon an early payment of his obligation. Better yet, the creditor might extend the date of the note. Sheppard's involvement with the "lower Class" against the "Magistrates" and his land purchase as a possible fair site, which the people "have very much at heart," were deliberate moves, "he being sensible an election would soon come."

The election outcome was not happenstance. The Quaker triumph was the product of better organization rather than questions of policy. The victors gleefully ascribed the decision to "tools continuously employed" and "unwearied industry." "The other party was very backward" and "broke to pieces."

The Cumberland election may be regarded as typical of colonial New Jersey's political life. Other elections in I 772 illustrated characteristics revealed in this broadside. Wealthy and influential interests contended for the prestige of political office and not for a set of ideas or programs. In Perth Amboy, for example, three candidates vied for two Assembly seats. The two winners, Cortlandt Skinner and John Combs, received 242 and 204 votes respectively, while Justin Homfray ran a poor third. ${ }^{9}$ No controversy appeared in the newspaper account, but attitudes toward the East Jersey Proprietors probably affected the contest. The Proprietors, centered in Perth Amboy, were large landholders and closely aligned with the Gov-

${ }^{\circ}$ New Jersey Archioes, Ist series, XXVIII, 100. 
ernor. Skinner was part of the "Perth Amboy Clique." Combs, on the other hand, probably opposed the proprietary interests. When the new Assembly met in August, I 772, an unsuccessful attempt was made by citizens from Perth Amboy's South Ward to have Combs' eleotion voided by claiming he lived in Monmouth County. ${ }^{10}$

This broadside affords merely a glimpse of provincial politics. The absence of similar documents, however, increases greatly the importance of the existing evidence. Of one thing we may be sure, political life was not dull. Many of the same characteristics of organization and conflict associated with the "sophisticated" practices of today were present. Even though no political parties existed, the "art of the possible" did not suffer from a lack of ingenuity. The Quakers of Cumberland County in March, I772, rivaled any of the political machines of the nineteenth and twentieth centuries.

10 Votes and Proceedings, Ist session, 22nd assembly, 8; 13-14. 